\title{
Medical Ethics - Are We Talking Enough
}

\author{
Shimpa Sharma ${ }^{1}$, Rakesh K. Sharma ${ }^{2}$, Rajesh K. Khyallapa ${ }^{3}$, Shweta Sharma ${ }^{4}$ \\ ${ }^{1}$ Pro-Vice Chancellor and Professor, Department of General Medicine, \\ ${ }^{2}$ Dean and Professor, Department of Obstetrics and Gynaecology, \\ ${ }^{3}$ Professor and Head, Department of General Medicine, \\ ${ }^{4}$ Intern, M.G.M. Hopsital and M.G.M. Medical College, Kamothe, Navi Mumbai. \\ 1,2,3 D.Y. Patil Medical College and D.Y. Patil Education Society Deemed University, Kolhapur \\ Corresponding Author: Shimpa Sharma \\ E-mail: shimpasharma@gmail.com
}

\begin{abstract}
The last three decades have seen major strides being made in the introduction and promotion of medical ethics in the medical school curriculum. Efforts to hone faculty skills and knowledge have come to the forefront. More emphasis has been placed on discussions on ethical issues in addition to subject-related deliberations. In India, medical ethics teaching remains largely a part of the 'hidden curriculum' in most colleges. This study aims to know the circumstances and opportunities currently available for the ethics education of students, a reflection of how far we have travelled on this path of delivering to society empathic and ethical physicians. It is of great pertinence in view of the fact that the Medical Council of India has from this year, included the teaching of ethics into the formal curriculum. It contributes to identifying wherefrom we start and focus our renewed efforts. Inclusion of what was earlier 'hidden' in the formal curriculum and its' implementation aim to ensure that the physicians of tomorrow acquire the knowledge and skills to recognize and handle ethical dilemmas in their practice.
\end{abstract}

Keywords: Ethics, medical students, medical, learning ethics, student uncertainty.

\section{INTRODUCTION}

In 1970, in one of her essays in the compilation "Sovereignty of God' philosopher Iris Murdoch stated that the ability of an individual to act in an appropriate manner 'when the time comes' "depends partly, perhaps largely, upon the quality of our habitual objects of attention" [1-2] Murdoch also recognized that choices can be made only within the world 'I can see', referring to the moral vision of an individual. Over two decades later PA Scott put forth an observation that "the quality of the practitioner's role enactment and moral sensitivity has a direct bearing upon patient care" [3]. These thoughts and observations when referenced to the field of medical ethics were before their times.

The World Medical Association at its' 51st annual General Assembly, held in Tel Aviv, Israel from October 13th -17th 1999, recommended "to all medical schools that the teaching of medical ethics and human rights be included as obligatory courses" [4]. The importance of ethics in medical education is irrefutable as is the emphasis on imparting this knowledge to all succeeding generations of doctors. Moral vision, so eloquently phrased by Murdoch, is increasingly a palpable 
felt need in the present context. So that some aspects of ethics do not become representative of the complex whole, a deliberate knowledge and understanding of the subject is essential.

The last three decades have seen major strides being made in the introduction and promotion of medical ethics in the medical school curriculum. Efforts to hone faculty skills and knowledge have come to the forefront. More emphasis has been placed on discussions on ethical issues in addition to subject-related deliberations. In India, medical ethics teaching remains largely a part of the 'hidden curriculum' in most colleges.

Despite efforts to bring ethics education to the mainstream of medical curriculum, there is always more that remains to be done. The question we have to ask ourselves is 'Are we doing enough?' To this end, it was decided to go to the students themselves who are our target learners.

This study aims to know the circumstances and opportunities currently available for the ethics education of students, a reflection of how far we have travelled on this path of delivering to society empathic and ethical physicians. It is of great pertinence in view of the fact that the Medical Council of India has from this year, included the teaching of ethics into the formal curriculum [1]. It contributes to identifying wherefrom we start and focus our renewed efforts.

\section{METHODOLOGY}

Following approval from the Institutional Ethics Committee, questionnaire was applied on 150 undergraduate (UG) and postgraduate medical students present on a routine working day, with a response rate of $72.6 \%(n=109)$. UG students were from the 8th and 9th Semesters (final years of MBBS). Responses were collected on the same day within 2 hours. Data regarding demography, prior ethics training was gathered. The questions are shown in the figure below. Data analysis was done using SPSS version 20.0

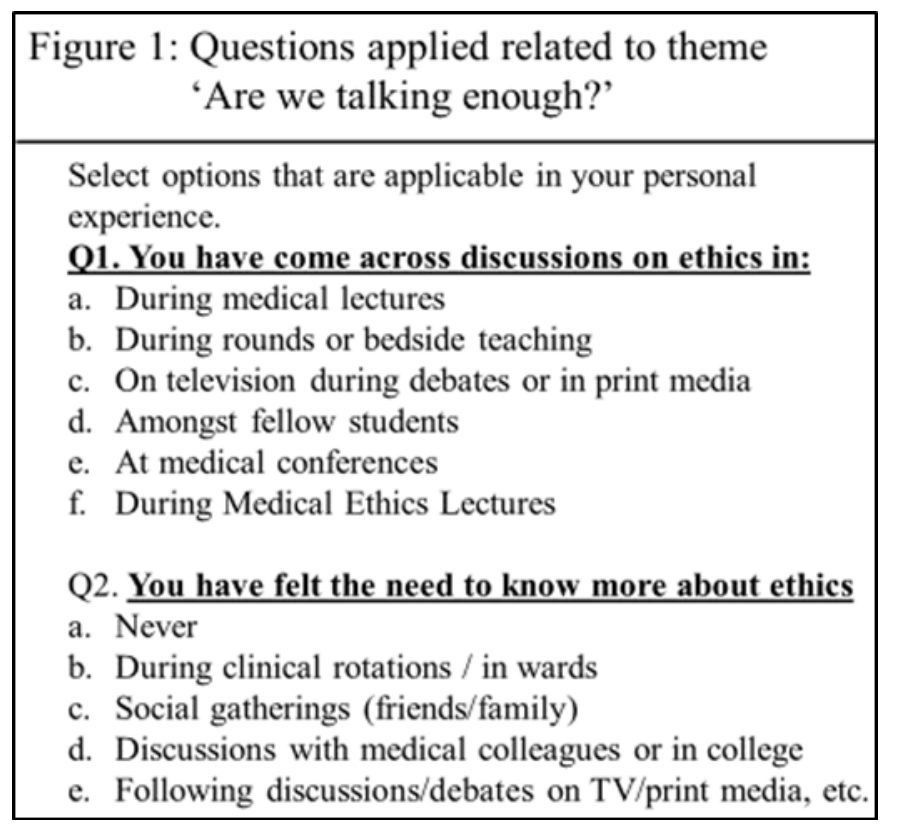

\section{RESULTS}

The sample consisted of 109 medical students and consisted of 47 undergraduate (UG) students and 62 post graduate (PG) students with a male:female ratio of $2.23: 1$. Of the respondents, $53.2 \%$ $(n=58)$ accepted that ethics had been covered in their curriculum while others either denied $(n=43)$ or were uncertain $(n=8)$. In response to where they had come across discussions on ethics the responses were varied. Significantly higher number of students agreed that discussions on ethics were seen in medical lectures $(\gamma(1)=11.239 ; \mathrm{p}=0.001)$, in the wards during bedside teaching or clinical rounds $(\gamma(1)=22.028 ; p=0.0001)$ and at conferences $(\gamma(1)=5.734 ; p=0.017)$. Interactions 
with other student-colleagues was not accepted as a likely source for ethics discussion $(\gamma(1)=4.046$; $\mathrm{p}=0.044)$.

Table 1 - Cross tabulation was done with the academic program of the respondent

\begin{tabular}{|c|c|c|c|c|c|c|c|c|}
\hline \multicolumn{9}{|c|}{ Responses to 'You have come across discussions on ethics in' } \\
\hline \multirow[t]{2}{*}{$\begin{array}{l}\text { Discussions } \\
\text { on ethics in }\end{array}$} & & \multirow[t]{2}{*}{ No } & \multirow[t]{2}{*}{ Yes } & \multicolumn{2}{|c|}{$\begin{array}{c}\text { Fishers Exact } \\
\text { Test }\end{array}$} & \multirow[t]{2}{*}{ OR } & \multirow[t]{2}{*}{$\begin{array}{c}95 \% \\
\text { CI }\end{array}$} & \multirow[t]{2}{*}{$\begin{array}{l}\text { RR of } \\
\text { 'No' }\end{array}$} \\
\hline & & & & 2-sided & 1-sided & & & \\
\hline \multirow{3}{*}{$\begin{array}{l}\text { Medical } \\
\text { Lectures }\end{array}$} & UG & 22 & 25 & \multirow[t]{3}{*}{0.016} & \multirow[t]{3}{*}{0.012} & \multirow[t]{3}{*}{0.363} & \multirow{3}{*}{$\begin{array}{l}0.160- \\
0.820\end{array}$} & \multirow[t]{3}{*}{1.935} \\
\hline & PG & 15 & 47 & & & & & \\
\hline & Total & 37 & 72 & & & & & \\
\hline \multirow[t]{3}{*}{ In Ward } & UG & 18 & 29 & \multirow[t]{3}{*}{0.033} & \multirow[t]{3}{*}{0.024} & \multirow[t]{3}{*}{0.387} & \multirow{3}{*}{$\begin{array}{l}0.163- \\
0.915\end{array}$} & \multirow[t]{3}{*}{1.979} \\
\hline & PG & 12 & 50 & & & & & \\
\hline & Total & 30 & 79 & & & & & \\
\hline \multirow[t]{3}{*}{ On Media } & UG & 28 & 19 & \multirow[t]{3}{*}{1.00} & \multirow[t]{3}{*}{0.516} & \multirow[t]{3}{*}{0.940} & \multirow{3}{*}{$\begin{array}{l}0.435- \\
2.030\end{array}$} & \multirow[t]{3}{*}{1.026} \\
\hline & PG & 36 & 26 & & & & & \\
\hline & Total & 64 & 45 & & & & & \\
\hline \multirow{3}{*}{$\begin{array}{l}\text { With other } \\
\text { Students }\end{array}$} & $\mathrm{UG}$ & 32 & 15 & \multirow[t]{3}{*}{0.167} & \multirow[t]{3}{*}{0.085} & \multirow[t]{3}{*}{0.533} & \multirow{3}{*}{$\begin{array}{l}0.242- \\
1.176\end{array}$} & \multirow[t]{3}{*}{1.279} \\
\hline & PG & 33 & 29 & & & & & \\
\hline & Total & 65 & 44 & & & & & \\
\hline \multirow{3}{*}{$\begin{array}{c}\text { In } \\
\text { Conference }\end{array}$} & $\overline{U G}$ & 17 & 30 & \multirow[t]{3}{*}{0.695} & 0.405 & 1.192 & $0.546-$ & 0.897 \\
\hline & PG & 25 & 37 & & & & 2.606 & \\
\hline & Total & 42 & 67 & & & & & \\
\hline Medical & UG & 26 & 21 & 0.032 & 0.020 & 0.414 & $0.190-$ & 1.633 \\
\hline Ethics & PG & 21 & 41 & & & & 0.902 & \\
\hline Lectures & Total & 47 & 62 & & & & & \\
\hline
\end{tabular}

Students who admittedly received ethics training in UG were 2.5 times more likely to accept that lectures on medical ethics enabled discussions on the subject $(\mathrm{p}<0.05)$ (Table 2)

Table 2 - Medical Ethics Lectures as discussion sources based on admitted UG ethics training

\begin{tabular}{|c|c|c|c|c|c|c|c|c|}
\hline \multirow{2}{*}{} & & \multicolumn{2}{|c|}{$\begin{array}{c}\text { Discussed in } \\
\text { ME lectures }\end{array}$} & \multicolumn{2}{|c|}{ Fisher's Exact test } & $\begin{array}{c}\text { Odds } \\
\text { Ratio }\end{array}$ & 95\% CI & $\begin{array}{c}\text { RR of } \\
\text { 'Yes' }\end{array}$ \\
\cline { 2 - 6 } & & Yes & No & 2-sided & 1-sided & & & \\
\hline \multirow{2}{*}{$\begin{array}{c}\text { ME } \\
\text { taught } \\
\text { in UG }\end{array}$} & Agreed & 39 & 19 & 0.022 & 0.016 & 2.499 & $1.148-5.439$ & 1.491 \\
\cline { 2 - 6 } & Not agreed & 23 & 28 & & & & & \\
\hline
\end{tabular}

Students were asked about the situations where they felt the need for further knowledge on ethics. Students revealed significantly higher need in the wards $(\mathrm{p}=0.003)$ and lower need was reported in social gatherings and while following media discussions or debates (both $p=0.0001$ ). Chi Square test revealed no significant difference in the need for ethics knowledge expressed by UG or PG students in different scenarios that were presented to them. (Table 3).

Analysis of responses with their self-admitted training in ethics revealed significant association with the need expressed is seen in Table 4.

\section{DISCUSSION}

Student uncertainty on whether or not ethics had been taught to them in their UG curriculum is worrisome, unless one considers that ethics so far in Indian medical colleges has been predominantly part of the 'informal' curriculum. The term in itself implies a certain laissez-faire 
approach to the transfer of knowledge, leaving the content, depth and extent of teaching to the judgement of the faculty.

Table 3: Felt need for knowledge of ethics in scenarios presented

\begin{tabular}{|c|c|c|c|c|c|c|c|c|}
\hline \multirow[t]{2}{*}{ Need } & \multirow[t]{2}{*}{ Group } & \multicolumn{2}{|c|}{ Need for knowledge } & \multicolumn{2}{|c|}{ Fisher Exact Test } & \multirow{2}{*}{$\begin{array}{l}\text { Odds } \\
\text { Ratio }\end{array}$} & \multirow[t]{2}{*}{ 95\% CI } & \multirow{2}{*}{$\begin{array}{l}\text { RR for } \\
\text { 'No' }\end{array}$} \\
\hline & & No & Yes & 2-sided & 1-sided & & & \\
\hline \multirow[t]{3}{*}{ Never } & UG & 40 & 7 & \multirow[t]{3}{*}{0.464} & \multirow[t]{3}{*}{0.289} & \multirow[t]{3}{*}{1.516} & \multirow[t]{3}{*}{$0.553-4.160$} & \multirow[t]{3}{*}{1.077} \\
\hline & $P G$ & 49 & 13 & & & & & \\
\hline & Total & 89 & 20 & & & & & \\
\hline \multirow{3}{*}{ Wards } & UG & 16 & 31 & \multirow{3}{*}{0.841} & \multirow[t]{3}{*}{0.45} & \multirow[t]{3}{*}{0.875} & \multirow[t]{3}{*}{$0.396-1.935$} & \multirow{3}{*}{0.918} \\
\hline & PG & 23 & 39 & & & & & \\
\hline & $\mathrm{T}$ & 39 & 70 & & & & & \\
\hline \multirow{3}{*}{$\begin{array}{l}\text { Social } \\
\text { Places }\end{array}$} & UG & 35 & 12 & \multirow[t]{3}{*}{1.00} & \multirow[t]{3}{*}{0.501} & \multirow[t]{3}{*}{1.102} & \multirow[t]{3}{*}{$0.466-2.600$} & \multirow[t]{3}{*}{1.026} \\
\hline & PG & 45 & 17 & & & & & \\
\hline & Total & 80 & 29 & & & & & \\
\hline \multirow[t]{3}{*}{ Colleagues } & UG & 20 & 27 & \multirow[t]{3}{*}{0.701} & \multirow[t]{3}{*}{0.404} & \multirow[t]{3}{*}{0.843} & \multirow[t]{3}{*}{$0.393-1.809$} & \multirow[t]{3}{*}{0.901} \\
\hline & PG & 29 & 33 & & & & & \\
\hline & Total & 49 & 60 & & & & & \\
\hline \multirow[t]{3}{*}{ Media } & UG & 36 & 11 & \multirow[t]{3}{*}{0.577} & \multirow[t]{3}{*}{0.268} & \multirow[t]{3}{*}{1.446} & \multirow[t]{3}{*}{$0.609-3.433$} & 1.104 \\
\hline & PG & 43 & 19 & & & & & \\
\hline & Total & 79 & 30 & & & & & \\
\hline
\end{tabular}

Table 4 - Discussions on Media as a source of felt need for ethics knowledge

\begin{tabular}{|c|c|c|c|c|c|c|c|c|}
\hline & & \multicolumn{2}{|c|}{$\begin{array}{l}\text { Discussions on } \\
\text { Media }\end{array}$} & \multicolumn{2}{|c|}{ Fisher's Exact test } & \multirow[t]{2}{*}{$\begin{array}{l}\text { Odds } \\
\text { Ratio }\end{array}$} & \multirow[t]{2}{*}{$95 \% \mathrm{CI}$} & \multirow[t]{2}{*}{$\begin{array}{l}\mathrm{RR} \text {, of } \\
\text { 'No' }\end{array}$} \\
\hline & & No & Yes & 2-sided & 1-sided & & & \\
\hline \multirow{3}{*}{$\begin{array}{l}\mathrm{ME} \\
\text { taught } \\
\text { in UG }\end{array}$} & Agreed & 48 & 10 & \multirow[t]{3}{*}{0.17} & \multirow[t]{3}{*}{0.009} & \multirow[t]{3}{*}{3.097} & \multirow[t]{3}{*}{$1.280-7.490$} & \multirow[t]{3}{*}{1.362} \\
\hline & Not agreed & 31 & 20 & & & & & \\
\hline & Total & 79 & 30 & & & & & \\
\hline
\end{tabular}

The ability to perceive and imbibe the teachings in the informal curriculum are dependent on multiple variables such as students' maturity, training in identifying the 'hidden curriculum', skill of the faculty, the context, timing of interaction, time for discussion, etc. Deliberate training has been shown to improve the ability of students to understand the hidden curriculum, appreciation of its' importance and ability to perceive good behavior in the wards [5].

The need to define the interventions in the 'hidden' curriculum has been recognized by several medical schools in different countries. India too joins this group with introduction of the Attitudes, Ethics and Communication (AETCOM) module in undergraduate medical curricula from the current academic year [6]. To the sensitized and experienced, all clinical situations and interactions have elements of ethical interest and seeds of discussion. It is heartening to note that students acknowledged the medical lectures, conferences and clinical postings/wards as places of ethical discussion in addition to Medical Ethics lectures (Table 1). It should be pointed out that while this number is statistically significant, ethics is not about statistics but about individuals. The focus and efforts of fine-tuning our system should continue till not the majority but all students are sensitized to recognizing ethical situations and being able and willing to discuss these with the same attention as they do a clinical diagnosis. The higher proportion of aware PG students in comparison to UG students is easily explained by the fact that they work longer with patients, are more likely to be presented with ethical issues, their one-on-one interaction with faculty is higher and these create a background for higher number, variety and depth of ethical discussions. Promoting discussions amongst students on ethical aspects of education and patient care is important. This has to be 
initiated and nurtured by the teachers and educators, creating an enabling and conducive environment for such discussions. However, it can only bear fruit if students are adequately sensitized, have the cognitive knowledge and are provided with a facilitative environment. Table 2 clearly depicts the difference made by students who self-admittedly were recipients of Medical ethics training, generating a hypothesis that they had attended the scheduled lectures on medical ethics. Since all students were from the same college and hence received similar overall training, the impact of formal training cannot be denied. It also underlines the fact that attendance in the lectures is directly correlated with outcomes [7].

The need to have had greater knowledge on ethics was noted by higher proportion of students in the wards and during discussions with colleagues. This reflects a degree of sensitization to ethical dilemmas amongst the students. Table 3 reveals that similar results for UG and PG students with regards to their responses which needs exploring. That medical school dehumanizes students is known [8-9]. It would be reasonable to expect greater empathy, recognition of ethical dilemma and need for knowledge as student's progress from undergraduate to postgraduate studies. The lack of this finding is cause for concern and introspection. The conversion of the expressed felt need to a confidence that translates into higher standards of patient care is the responsibility of the faculty. A formal curriculum would definitely contribute to this end.

It is pertinent to note that most courses do not address ethics from the perspective of student experiences during medical training. Contradictions between what is taught and actually practiced, students' difficulties in adhering to ethical precepts, the silent compulsions of their position in the hierarchal medical structure, temptation to withhold information from patients are some areas not routinely covered [10]. The courses designed need to be relevant and interesting to hold their attention and make a palpable difference in their practice. Several authors have noted that students have definite preference of topics they consider relevant [10-14]. Maturity of a curriculum would be when its' contents satisfy the needs of a learner and the end-beneficiaries - the patient. This strengthens the case for stakeholder participation in curriculum designing.

Another point made by students in this study was with reference to the Media. The media (TV or print) was not seen either as a platform where discussions on ethics happened and neither did students feel the need for knowledge on ethics in that setting. This is a poor commentary on the content of various media modalities that do not deal with topics of ethical interest in a befitting manner. Concern over market share and ratings have resulted in media converting ethical issues into sensational news with more emphasis on blame game and retribution than on the issue itself. However, it is to be accepted that a mature physician would be able to identify the ethical aspects of such media coverage.

\section{CONCLUSION}

The study underlines the need for greater extent and depth of training on medical ethics for our students. The medical student is an impressionable mind that we as faculty can embed with ethical values and knowledge that will beget a caring physician. Great hopes are placed on the introduction in the formal curriculum of the AETCOM module. There is an old saying, 'It takes a village to raise a child'. Let us all, physicians, educators, patients and the media, unite to raising a professional, ethical physician for tomorrow.

\section{REFERENCES}

1. https://www.mciindia.org/CMS/wp-content/uploads/2019/01/AETCOM_book.pdf Accessed on 12th May 2019

2. Murdoch I. The Sovereignty of Good. 1st Ed. Routledge Classics. London, England: Routledge \& Kegan Paul;1970.

3. Scott PA. Role, role enactment and the health care practitioner J Adv Nurs 1995;22(2):323-8.

4. https://www.wma.net/news-post/51st-annual-general-assembly-of-the-world-medicalassociation/ Accessed on 16th May 2019

5. Hopkins, L, Saciragic L, Kim J, Posner G. The Hidden Curriculum: Exposing the Unintended Lessons of Medical Education Cureus; Palo Alto 2016;8(10):1-5 
6. https://www.mciindia.org/CMS/wp-content/uploads/2019/01/AETCOM_book.pdf Accessed on 12th May 2019.

7. Sharma S, Sharma R K Medical College Attendance-Relevance in an Era of E-learning. J Res Med Educ Ethics 2018;8(3):205-10.

8. Geiger HJ. The causes of dehumanization in health care and prospects for humanization. In: Howard J Strauss A, eds. Humanizing Health Care. New York: John Wiley, 1975: 11-36.

9. Haque OS, Waytz A. Dehumanization in Medicine: Causes, Solutions, and Functions. Persp Psychol Sci 2012;7(2):176-86.

10. St Onge J. Medical education must make room for student-specific ethical dilemmas, Can Med Assoc J 1997;56(4):1175-7.

11. Rhodes R, Cohen, D S. Understanding, Being, And Doing: Medical Ethics in Medical Education. Cambridge Quart Healthcare Ethics 2003;12(1):39-53.

12. Musick DW. Teaching medical ethics: A review of the literature from North American medical schools with emphasis on education: Med Health Care Philos 1999;2:239-54.

13. Mijaljica G. Medical Ethics, Bioethics and Research Ethics Education Perspectives in South East Europe in Graduate Medical Education. Sci Eng Ethics 2014;20:237-47.

14. Terndrup C. A Student's Perspective on Medical Ethics Education J Relig Health 2013;52:1073-8.

Acknowledgements: All the students that participated in the study

Financial grants for this paper: Nil

Conflict of interest: None 